\title{
ANALISIS POTENSI TINDAK PIDANA KORUPSI DALAM PELAKSANAAN TUGAS DAN JABATAN NOTARIS DAN PEJABAT PEMBUAT AKTA TANAH
}

\author{
Tresya $^{1}$ \\ Universitas Batanghari Jl. Slamet Riyadi Brorni Kota Jambi (0741) 65351 \\ Email : Tresyashmh@gamil.com
}

\begin{abstract}
Abstrak
Penelitian ini bertujan untuk mengetahui dan mengenalisis : (1) Perbuatan perbuatan apa saja yang berpotensi sebagai tindak pidana korupsi dalam pelaksanaan tugas dan jabatan Notaris dan PPAT dan (2) upaya yang dilakukan oleh Notaris dan PPAT dalam mencegah perbuatannya agar tidak berpotensi sebagai tindak pidana korupsi Penelitian ini merupakan penelitian normatif empiris karena dalam penelitian ini penulis memadukan penelitian hukum normatif (data - data sekunder) dengan penelitian hukum empiris (data - data primer yang diperoleh dari hasil penelitian di lapangan). Narasumber dari Penelitian ini adalah Notaris dalam wilayah kerja kota Jambi dan akademisi. Teknik pengambilan sampel yang digunakan adalah purposive sampling. Metode analisis yang digunakan dalam penelitian ini adalah metode berpikir analisis kualitatif dan penarikan kesimpulannya menggunakan metode berpikir induktif. Hasil penelitian ini menujukan bahwa perbuatan - perbuatan yang berpotensi sebagai tindak pidana korupsi dalam pelaksanaan tugas dan jabatan Notaris dan Pejabat Pembuat Akta Tanah adalah terdapat dalam Pasal 2, 3, 5, 10 dan Pasal 12 huruf h Undang-undang Nomor 20 Tahun 2001 tentang perubahan atas Undang undang Nomor 31 Tahun 1999 tentang Pemberantasan Tindak Pidana Korupsi. Beberapa pasal menunjukan potensi Notaris dan PPAT dapat dikenakan pasalpasal tersebut jika melakukan tindak pidana korupsi. Dalam hal upaya pencegahan perbuatannya agar tidak berpotensi sebagai tindak pidan Korupsi adalah dengan bekerja secara professional sesuai dengan Undang - undang yang berlaku, dan Kode etik Notaris dan PPAT.

Kata Kunci : Notaris, PPAT, Tindak Pidana Korupsi
\end{abstract}

\begin{abstract}
This research is raining to know and recognize: (1) Any actions that have potential as corruption in the execution of duties and positions of Notary and PPAT (2) the efforts made by Notary and PPAT in preventing their actions to not have the potential to be criminal act of corruption This research is an empirical normative research because in this study the authors combine normative legal research (secondary data) with empirical legal research (primary data obtained from research results in the field). The source of this research is Notary in the working area of Jambi city and academician. The sampling technique used is purposive sampling. The method of analysis used in this study is the method of thinking qualitative analysis and drawing conclusions using inductive thinking methods. The results of this study indicate that potential acts as corrupt offenses in the performance of duties and positions of Notary and Officials of the Deed of
\end{abstract}

\footnotetext{
${ }^{1}$ Tresya, SH, MH,. Dosen Tetap PS Ilmu Hukum Fakultas Hukum Universitas Batanghari Jambi
}

Analisis Potensi Tindak Pidana Korupsi Dalam Pelaksanaan Tugas dan Jabatan Notaris dan Pejabat Pembuat Akta Tanah 
Land are contained in Article 2, 3, 5, 10 and Article 12 Sub-Article H of Law Number 20 Year 2001 concerning the amendment of Law Number 31 Year 1999 concerning the Eradication of Corruption. Several articles indicate the potential of Notary and PPAT may be subject to those articles if they commit a criminal act of corruption. In the case of the prevention of his actions so as not to have the potential to act Corruption is to work professionally in accordance with the applicable Law, and Notary Code of Ethics and PPAT.

\section{Keywords: Notary Public, PPAT, Corruption}

\section{PENDAHULUAN}

Salah satu permasalahan yang besar dan bukan menjadi hal yang langka terjadi di Indonesia adalah masalah korupsi. Korupsi bukan masalah baru dalam persoalan hukum dan ekonomi bagi suatu negara, karena sebenarnya korupsi telah ada sejak lama baik di negara maju maupun negara berkembang seperti halnya Indonesia. Korupsi menjadi masalah yang sangat luar biasa karena sudah meningkat dan menyebar ke seluruh lapisan masyarakat termasuk di Indonesia. ${ }^{2}$

Tindak pidana korupsi di Indonesia terus menunjukkan peningkatan dari tahun ke tahun. Tindak pidana korupsi sudah meluas dalam masyarakat, baik dari jumlah kasus yang terjadi dan jumlah kerugian negara, maupun dari kualitas tindak pidana yang dilakukan semakin sistematis dan lingkupnya yang memasuki seluruh aspek kehidupan masyarakat. ${ }^{3}$ Teori yang menyatakan bahwa hanya masyarakat miskin mudah terjadi kejahatan, sudah tidak berlaku lagi. Hal tersebut karena pada era globalisasi justru muncul kejahatan baru, khususnya di lingkungan birokrasi dan perusahaan-perusahaan termasuk bank-bank. ${ }^{4}$

Salah satu bentuk penanggulangan terhadap tindak pidana korupsi dengan keluarnya Undang-Undang Nomor 31 Tahun 1999 tentang Pemberantasan Tidak Pidana Korupsi sebagaimana telah diubah dengan Undang-Undang Nomor 20 Tahun 2001 tentang Perubahan atas Undang- Undang Nomor 31 Tahun 1999 tentang Pemberantasan Tindak Pidana Korupsi. Keluarnya Undang-Undang ini terkait dengan didasari pemikiran bahwa tindak pidana korupsi sangat merugikan keuangan negara atau perekonomian negara dan menghambat pembangunan nasional, sehingga harus diberantas dalam rangka mewujudkan masyarakat adil dan makmur berdasarkan Pancasila dan Undang - Undang Dasar Negara Republik Indonesia Tahun 1945, serta bahwa akibat tindak pidana korupsi yang terjadi selama ini selain merugikan keuangan negara atau perekonomian negara, juga menghambat pertumbuhan dan kelangsungan pembangunan nasional yang menuntut efisiensi tinggi.

Potensi tindak pidana korupsi dapat dilakukan oleh seluruh lapisan masyarakat, termasuk jabatan Notaris dan Pejabat Pembuat Akta Tanah (PPAT). Dalam kamus besar bahasa Indonesia potensi adalah kemampuan yang mempunyai kemungkinan untuk dikembangkan, kekuatan, kesanggupan, daya, sehingga dalam hal ini Notaris dan PPAT dalam menjalankan tugas dan jabatannya mempunyai kemungkinan untuk melakukan tindak pidana korupsi. Sebagaimana diketahui Notaris dan PPAT memiliki peran yang sangat penting

\footnotetext{
${ }^{2}$ Youngky Putra, "Pertanggung Jawaban Korporasi dalam tindak pidana korupsi”, http://karyatulisa.com/2012/06/12_23.html, diakses tanggal 28 April 2017

${ }^{3}$ Ibid,.

${ }^{4}$ Baharudin Lopa, Kejahatan Korupsi dan Penegakan Hukum, Buku Kompas, Jakarta, 2012, hlm 35
} 
dalam menjamin kepastian, ketertiban dan perlindungan hukum melalui produkproduk akta yang dibuatnya.

Suatu tindakan yang keliru dari Notaris dan PPAT dalam menjalankan tugas dan jabatannya tidak hanya akan merugikan Notaris dan PPAT itu sendiri, namun juga akan merugikan organisasi, masyarakat dan negara. Pelanggaran pada jabatan Notaris dan PPAT terjadi apabila Notaris dan PPAT melanggar peraturan perundang-undangan, serta etika profesi atau Kode etik Notaris dan PPAT, kesusilaan, dan ketertiban umum. Nilai lebih dari suatu profesi adalah sejauh mana seorang profesional mampu menahan godaan atas kepercayaan yang diemban kepadanya padahal godaan untuk menyelewengkan kepercayaan begitu besar. $^{5}$

Seperti yang telah dijelaskan di atas bahwa tindak pidana korupsi dapat dilakukan oleh seluruh lapisan masyarakat, termasuk jabatan Notaris dan PPAT. Hal ini dapat dilihat dengan berbagai kasus-kasus korupsi yang menjerat Notaris dan PPAT di Indonesia, seperti kasus yang terjadi di Semarang, Jawa Tengah, seorang Notaris dan PPAT berinisial DS ditahan karena memalsukan dan tidak menyetorkan uang pajak dalam sebuah transaksi jual beli rumah. Tindak pidana itu sendiri, bermula ketika Tersangka DS bersama dua tersangka lain yang disidik dalam berkas terpisah, masing-masing SM dan KE melakukan peralihan hak atas tanah di kantor Badan Pertanahan Kota Semarang.

Tersangka diketahui menggunakan bukti pembayaran bea perolehan hak atas tanah dan bangunan (BPHTB) dan pajak pertambahan nilai (PPN) palsu dalam proses tersebut. Atas perbuatannya itu, negara dirugikan sekitar Rp 823.000.000,- Perbuatan para Tersangka selanjutnya dijerat dengan UndangUndang Nomor 31 tahun 1999 tentang Pemberantasan Tindak Pidana Korupsi yang telah diubah dengan Undang - Undang Nomor 20 Tahun 2001 juncto Pasal 55 ayat 1 ke- 1 KUHP. ${ }^{6}$ Berkas perkara kasus ini dilimpahkan ke pengadilan Tipikor Semarang, dan telah sampai pada putusan akhir yakni Terdakwa DS dijatuhi pidana penjara selama 1 Tahun dikarenakan terbukti menurut hukum bersalah melakukan tindak pidana Korupsi, serta didenda sebesar Rp 50.000.000,(lima puluh juta rupiah), subsider 2 (dua) bulan penjara. ${ }^{7}$

Bertolak dari uraian latar belakang masalah di atas penulis tertarik untuk melakukan penelitian tentang ANALISIS POTENSI TINDAK PIDANA KORUPSI DALAM PELAKSANAAN TUGAS DAN JABATAN NOTARIS DAN PEJABAT PEMBUAT AKTA TANAH.

\section{Rumusan Masalah}

Berdasarkan uraian latar belakang masalah yang telah dipaparkan tersebut di atas penulis merumuskan permasalahan sebagai berikut:

1. Perbuatan-perbuatan apa saja yang berpotensi sebagai tindak pidana korupsi dalam pelaksanaan tugas dan jabatan Notaris dan PPAT?

${ }^{5}$ Abdul Ghofur Anshori, Lembaga Kenotariatan Indonesia Prespektif Hukum dan Etika, UII Press, Yogyakarta, 2009, hlm 1.

6“Seorang Notaris ditahan karena gelapkan pajak"

http://www.republika.co.id/berita/nasional/hukum/15/10/28/nwxfj6219-seorang-notaris ditahankarena-gelapkan-pajak diaskes tanggal 28 April 2017

7“Notaris Damar Susilowati Divonis Satu Tahun" http://nyerah.com/berita/notaris-damarsusilowatidivonis-satu-tahun-33734/" diakses tanggal 28 April 2017

Analisis Potensi Tindak Pidana Korupsi Dalam Pelaksanaan Tugas dan Jabatan Notaris dan Pejabat Pembuat Akta Tanah 
2. Bagaimanakah upaya yang dilakukan oleh Notaris dan PPAT dalam mencegah perbuatannya agar tidak berpotensi sebagai tindak pidana korupsi?

\section{METODE PENELITIAN}

Menurut Soejono Soekamto metode penelitian adalah proses, prinsip-prinsip dan tata cara untuk memecahkan masalah yang dihadapi dalam melakukan penelitian. $^{8}$

Jenis Penelitian ini digunakan adalah penelitian normatif empiris. Pada dasarnya merupakan penggabungan antara pendekatan hukum normatif dengan adanya penambahan berbagai unsur empiris. Metode penelitian normatif-empiris mengenai implementasi ketentuan hukum normatif (undang-undang) dalam aksinya pada setiap peristiwa hukum tertentu yang terjadi dalam suatu masyarakat.

Bahan penelitian ini adalah

1. Studi Pustaka, Penelitian ini dilakukan dengan menelaah buku-buku literatur, peraturan perundang-undangan dan dokumen-dokumen yang relevan dengan pokok bahan skripsi. Hasil dari menelaah buku-buku dan lainnya dimaksudkan untuk mengambil intisarnya sebagai data skunder yang berguna untuk menyusun dan merumuskan kerangka teori skripsi ini. Peraturan perundangundangan : Undang-Undang Nomor 31 Tahun 1999 sebagaimana telah diubah menjadi Undang-Undang Nomor 20 Tahun 2001 tentang Pemberantasan Tindak Pidana Korupsi (UUPTPK), Undang - Undang Nomor 30 Tahun 2004 sebagaimana telah diubah menjadi Undang - Undang Nomor 2 Tahun 2014 tentang Jabatan Notaris Peraturan Pemerintah Nomor 37 Tahun 1998 tentang Pejabat Pembuat Akta Tanah sebagaimana telah di ubah menjadi Peraturan Pemerintah Nomor 24 Tahun 2016 tentang Pejabat Pembuat Akta Tanah

2. Studi Lapangan, Sebagai tindak lanjut dari hasil penelitian kepusatakan di atas, maka penulis melakukan juga penelitian lapangan untuk mendapatkan data primer yang berguna untuk dapat mendeskripsikan masalah dalam pembahasan penelitian ini, data diperoleh langsung berhadapan dengan objek penelitian.

Lokasi dan subjek dalam penilitian ini adalah notaris dan PPAT yang wilayah kerjanya di Kota Jambi.

Teknik Penarikan Sampel dilakukan dengan cara purposive sampling, yaitu penarikan sampel dengan terlebih dahulu menentukan kriteria yang diteliti. Kriteria yang digunakan di sini adalah mereka yang dianggap lebih mengetahui atau memahami tentang masalah yang diteliti. Adapun sampel yang memenuhi kriteria dimaksud adalah : Notaris dan PPAT Kota Jambi.

Teknik Analisis Data adalah data yang diperoleh kemudian di analisis dengan metode analisis kualitatif, yaitu analisis yang menekankan pada penjelasan dengan menggunakan kalimat-kalimat dari apa yang telah diperoleh sewaktu penelitian, yang kemudian dapat ditarik suatu kesimpulan yang bersifat induktif (menganalisis permasalahan dari suatu kejadian nyata dan menariknya dalam suatu kesimpulan yang bersifat umum).

\section{HASIL DAN PEMBAHASAN}

Perbuatan-perbuatan yang berpotensi sebagai tindak pidana korupsi dalam pelaksanaan tugas dan jabatan Notaris dan PPAT

\footnotetext{
${ }^{8}$ Soerjono Soekamto, Pengantar Penelitian Hukum, Jakarta : UI Press, hlm. 6
} 
Notaris adalah pejabat umum yang berwenang membuat akta otentik dan kewenangan lainnya sebagaimana dimaksud dalam Pasal 1 angka 1 UndangUndang Nomor 2 Tahun 2014 tentang Perubahan atas Undang-undang Nomor 30 Tahun 2004 tentang Jabatan Notaris. Notaris berwenang membuat akta otentik dan memiliki posisi yang strategis dalam memberikan kepastian hukum kepada masyarakat khususnya bidang perikatan yang terjadi karena perjanjian. Ruang lingkup pertanggungjawaban Notaris meliputi kebenaran formil atas akta yang dibuatnya. Melalui akta yang dibuatnya, Notaris harus dapat memberikan kepastian hukum kepada masyarakat pengguna jasa Notaris. Sedangkan Peraturan Pemerintah Nomor 24 Tahun 2016 tentang perubahan atas Peraturan Pemerintah Nomor 37 Tahun 1998 tentang Peraturan Jabatan Pejabat Pembuat Akta Tanah adalah landasan hukum terhadap keberadaan PPAT. Dalam Peraturan Pemerintah ini dijelaskan bahwa PPAT adalah pejabat umum yang diberi kewenangan untuk membuat akta-akta otentik mengenai perbuatan hukum tertentu mengenai hak atas tanah atau hak milik atas satuan rumah susun.

Perbuatan-perbuatan yang berpotensi sebagai tindak pidana Korupsi dalam tugas dan jabatan Notaris dan PPAT terdapat dalam Pasal 2, 3, 5, 10, 12 huruf h dan Pasal 13 Undang-undang Nomor 20 Tahun 2001 tentang Perubahan atas Undang-undang Nomor 31 Tahun 1999 tentang Pemberantasan Tindak Pidana Korupsi yakni :

1. Perbuatan yang secara melawan hukum melakukan perbuatan memperkaya diri sendiri atau suatu korporasi yang dapat merugikan Negara dan perekonomian Negara. (Pasal 2)

2. Perbuatan menguntungkan diri sendiri atau orang lain atau korporasi, menyalahgunakan kewenangan, kesempatan atau sarana yang ada padannya karena jabatan atau kedudukan yang dapat merugikan keuangan Negara atau perekonomian Negara. (Pasal 3)

3. Memberi atau menjanjikan sesuatu kepada pegawai negeri atau penyelenggara Negara dengan maksud supaya pegawai negeri atau penyelenggara Negara tersebut berbuat atau tidak berbuat sesuatu dalam jabatannya, yang bertentangan dengan kewajibannya. (Pasal 5 huruf a )

4. Memberi sesuatu kepada pegawai negeri atau penyelenggara Negara karena berhubungan dengan sesuatu yang bertentangan dengan kewajiban, dilakukan atau tidak dilakukan dalam jabatannya. (Pasal 5 huruf b)

5. Menggelapkan, menghancurkan, merusakkan atau membuat tidak dapat dipakai barang, akta, surat atau daftar yang digunakan untuk meyakinkan atau membuktikan di muka pejabat yang berwenang yang dikuasai karena jabatannya (Pasal 10 huruf a)

6. Membiarkan orang lain menghilangkan, menghancurkan, merusakkan, atau membuat tidak dapat dipakai barang, akta, surat, atau daftar tersebut (Pasal 10 huruf $b$ )

7. Membantu orang lain menghilangkan, menghancurkan, merusakkan, atau membuat tidak dapat dipakai barang, akta, surat, atau daftar tersebut. (Pasal 10 huruf c)

8. Perbuatan dimana pegawai negeri atau penyelenggara Negara yang pada waktu menjalankan tugas telah menggunakan tanah Negara yang diatasnya terdapat hak pakai, seolah-olah sesuai dengan peraturan perundang-undangan, telah merugikan orang yang berhak, padahal diketahuinya bahwa perbuatan tersebut bertentangan dengan peraturan perundang-undangan. (Pasal 12 huruf $h$ ) 
9. Perbuatan memberi hadiah atau janji kepada pegawai negeri dengan mengingat kekuasaan atau wewenang yang melekat pada jabatan atau kedudukannya, atau oleh pemberi hadiah atau janji dianggap melekat pada jabatan atau kedudukan tersebut (Pasal 13)

Dalam Pasal-pasal tersebut terdapat potensi tindak pidana korupsi yang dapat menjerat Notaris dan PPAT dalam pelaksanan tugas dan jabatannya, baik menjadi tersangka maupun menjadi turut serta dalam kasus korupsi ini. Kasus yang terjadi di Indonesia yang menjerat Notaris melakukan tindak pidana Korupsi adalah dengan membuat Cover Note untuk angunan kredit pada Badan Usaha Milik Negara, dan tanpa diperiksa terlebih dahulu keberadaan angunanya, baik secara fisik maupun dokumen-dokumennya. Sedangkan pada PPAT adalah menyalahgunakan kewenangannya sebagai PPAT untuk membuat suatu akta yang obyeknya tidak ada, dengan para pihak berasal dari Pegawai Negeri Sipil. Selain itu adalah penggelapan pajak BPHTB dan PPH yang sering dilakukan oleh PPAT dalam transaksi jual beli tanah, baik tidak dibayarkan, maupun dibayarkan dengan harga yang bukan sebenarnya juga merupakan tindak pidana Korupsi yang dilakukan oleh PPAT namun hal ini bukanlah tugas dan wawenang seorang PPAT karena seperti yang sudah dijelaskan diatas bahwa untuk pembayaran pajak adalah tugas dari klien (wajib pajak) dengan Negara, bukan merupakan tugas PPAT, namun hal ini selalu menjadi faktor utama terjadinya kasus korupsi di kalangan Pejabat umum.

Dari keseluruhan, Pasal yang paling berpotensial adalah Pasal 2, dan Pasal 3 mengenai kerugian Negara karena Pasal ini cakupanya cukup luas, sehingga sering digunakan ketika terdapat tindak pidana korupsi, dalam pelaksanaan tugas dan jabatan Notaris dan PPAT akan disertai dengan Pasal 55 KUHP.

\section{Upaya yang dilakukan oleh Notaris dan PPAT dalam mencegah perbuatannya agar tidak berpotensi sebagai tindak pidana korupsi}

Notaris diminta selalu berpedoman pada kode etik profesi dan UndangUndang Nomor 2 Tahun 2014 tentang Jabatan Notaris. Ini karena jabatan notaris dinilai mudah tergelincir pada hal-hal yang merugikan dan melanggar kode etik profesi.

Dalam memberikan pelayanan kepada masyarakat harus senantiasa berpedoman kode etik profesi dan berdasarkan Undang - Undang tentang Jabatan Notaris, yaitu Undang - Undang Nomor 2 Tahun 2014. Untuk mencegah dan menghapus korupsi, kolusi dan nepotisme, serta suap sekaligus menciptakan tata kelola pemerintahan yang bersih, telah ditetapkan penggunaan teknologi informasi online pada seluruh notaris. Misalnya dalam pengurusan untuk memperoleh keputusan menteri mengenai pengesahan badan hukum perseroan, seperti diatur dalam Undang - Undang Nomor 40/2007.

Upaya yang dilakukan dalam pencegahan tindak pidana Korupsi dalam tugas dan jabatan Notaris dan PPAT adalah :

1. Notaris dan PPAT tidak melakukan hal-hal yang bukan menjadi tugas dan wewenang dari Notaris dan PPAT, serta melakukan tugas dan jabatan sesuai dengan Undang-undang yang berlaku, dan kode etik. Dengan bekerja secara professional dan sesuai dengan ketentuan undang-undang maka tidak akan terjadi tindak pidana pada umumnya dan tindak pidana Korupsi pada khususnya. 
2. Notaris dan PPAT mendekatkan diri kepada Tuhan Yang Maha Esa. Agar moral, etika dapat terarah kepada hal yang lebih positif.

3. Notaris dan PPAT untuk bersikap jujur. Kejujuran adalah nilai yang sudah tidak terlalu dijunjung tinggi oleh masyarakat, saat ini sepertinya sulit menemukan orang yang masih mengutamakan kejujuran. Kejujuran merupakan kunci utama dalam mencegah terjadinya korupsi. Notaris dan PPAT harus membiasakan diri untuk berlaku jujur dimanapun berada.

4. Notaris dan PPAT harus bertanggungjawab. Menumbuhkan sikap tanggung jawab pada diri kita. Sikap bertanggung jawab harus dipupuk sejak dini karena perbuatan korupsi juga berasal dari pelarian tanggung jawab. Korupsi memancarkan sikap yang pengecut yang tidak mau menanggung segala akibat dari perbuatannya yang tidak jujur. Bertanggung jawab berarti menanggung apa yang menjadi akibat dari perbuatan kita.

5. Notaris dan PPAT bersikap kritis. Bersikap kritis artinya menyikapi segala sesuatu berdasarkan pikiran yang matang dan logis.

Berdasarkan wawancara penulis dengan Notaris Kota Jambi Ibu Triamy, $\mathrm{SH}, \mathrm{M} . \mathrm{Kn}$. Beliau mengatakan sebagai seorang notaris harus menghindari perbuatan tersebut dengan cara mengedukasi diri sendiri tentang pengertian korupsi, bahaya korupsi dan resiko dari perbuatan korupsi tersebut.

Selain itu, beliau juga mengungkapkan bahwa Sesuai Pasal 68 ayat (1) Undang - Undang Jabatan Notaris Majelis Pengawas Notaris terdiri dari Majelis Pengawas Daerah, Majelis Pengawas Wilayah, dan Majelis Pengawas Pusat. Majelis Pengawas Daerah merupakan pengawas Notaris pada tingkat pemeriksaan pertama, sehingga pihak yang dirugikan oleh Notaris melapor kepada Majelis Pengawas Daerah yang berkedudukan di Kabupaten atau Kota.

Kewenangan Majelis Pengawas Daerah di sebutkan dalam Pasal 70 Undang - Undang Jabatan Notaris antara lain adalah:

1. menyelenggarakan sidang untuk memeriksa adanya dugaan pelanggaran Kode Etik Notaris atau pelanggaran pelaksanaan jabatan Notaris; serta

2. menerima laporan dari masyarakat mengenai adanya dugaan pelanggaran Kode Etik Notaris atau pelanggaran ketentuan dalam Undang-Undang.

Menurut hemat penulis, berdasarkan wawancara dengan Ibu Triamy, bahwa apapun yang dilakukan notaris mendapatkan pengawasan dari Majelis Pengawas. Sehingga terdapat duo control terhadap tugas dan weweng yang notaris dan PPAT lakukan.

\section{KESIMPULAN}

Berdasarkan hasil pembahasan dalam penelitian ini, maka dapat diambil kesimpulan sebagai berikut :

1. Perbuatan-perbuatan yang berpotensi sebagai tindak pidana Korupsi dalam tugas dan jabatan Notaris dan PPAT terdapat dalam Pasal 2, 3, 5, 10, 12 huruf h dan Pasal 13 Undang-undang Nomor 20 Tahun 2001 tentang Perubahan atas Undang-undang Nomor 31 Tahun 1999 tentang Pemberantasan Tindak Pidana Korupsi.

2. Upaya yang dilakukan dalam pencegahan tindak pidana Korupsi dalam tugas dan jabatan Notaris dan PPAT adalah dengan tidak melakukan hal-hal yang bukan menjadi tugas dan wewenang dari Notaris dan PPAT, serta melakukan tugas dan jabatan sesuai dengan Undang-undang yang berlaku, dan kode etik. Dengan bekerja secara professional dan sesuai dengan ketentuan undang- 
undang maka tidak akan terjadi tindak pidana pada umumnya dan tindak pidana Korupsi pada khususnya. Serta memperbaiki moral dengan cara mendekatkan diri kepada Tuhan Yang Maha Esa. Agar moral, etika dapat terarah kepada hal yang lebih positif dan juga melatih para Notaris dan PPAT untuk bersikap jujur dan bertanggungjawab.

\section{Saran}

Berdasarkan uraian hasil analisis potensi tindak pidana korupsi dalam pelaksanaan tugas dan jabatan Notaris dan Pejabat Pembuat Akta Tanah penulis memberikan saran sebagai berikut:

1. Kepada Notaris dan Pejabat Pembuat Akta Tanah agar menyadari bahwa bekerja secara professional, bekerja sesuai dengan peraturan dan kode etik yang berlaku akan membuat hidup lebih nyaman tanpa ada kekhawatiran dalam bekerja sebagai Notaris dan PPAT.

\section{DAFTAR PUSTAKA}

\section{Pustaka dari Buku}

Abdul Ghofur Anshori, Lembaga Kenotariatan Indonesia Prespektif Hukum dan Etika, UII Press, Yogyakarta, 2009

Baharudin Lopa, Kejahatan Korupsi dan Penegakan Hukum, Buku Kompas, Jakarta, 2012

Soerjono Soekamto, Pengantar Penelitian Hukum, Jakarta : UI Press

\section{Pustaka dari Peraturan Perundang-undangan}

Undang-Undang Nomor 20 Tahun 2001 Tentang Perubahan atas Undang-Undang Nomor 31 Tahun 1999 Tentang Pemberantasan Tindak Pidana Korupsi

Peraturan Kepala BPN RI No 1 Tahun 2006 Tentang Ketentuan Pelaksanaan Peraturan Pemerintah Nomor 24 Tahun 2016 Tentang Perubahan atas Peraturan Pemerintah Nomor 37 Tahun 1998 tentang Peraturan Jabtatan Pejabat Pembuat Akta Tanah

\section{Pustaka Artikel dari Internet}

Youngky Putra, "Pertanggung Jawaban Korporasi dalam tindak pidana korupsi", http://karyatulisa.com/2012/06/12_23.html, diakses tanggal 28/04/ 2017

Seorang Notaris ditahan karena gelapkan pajak" http://www.republika.co.id/berita/nasional/hukum/15/10/28/nwxfj6219seorangnotaris-ditahan-karena-gelapkan-pajak diaskes tanggal 28/04/2017

Joker "Notaris Damar Susilowati Divonis Satu Tahun" http://nyerah.com/berita/notarisdamar-susilowati-divonis-satu-tahun33734/" diakses tanggal 28/04/2017 